\title{
RETURN SAHAM : KARAKTERISTIK PERUSAHAAN DAN INFLASI (STUDI EMPIRIS PADA PERUSAHAAN MANUFAKTUR SEKTOR BARANG KONSUMSI YANG TERDAFTAR PADA BURSA EFEK INDONESIA)
}

\author{
Oleh: \\ Franky Okto Bernando \\ (Dosen Prodi Manajemen STIE Pelita Bangsa)
}

\begin{abstract}
Abstrak : Manufaktur sektor barang konsumsi merupakan salah satu industri yang berada pada tingkat persaingan yang cukup ketat dan mempunyai kinerja relatif stabil. Investor menilai bahwa manufaktur sektor barang konsumsi tidak hanya menjadi kebutuhan manusia namun juga dapat menjadi investasi yang baik yang baik untuk masa yang akan datang. Peningkatan perusahaan manufaktur sektor barang konsumsi di Bursa Efek menunjukkan bahwa investasi ini menarik bagi investor untuk menginvestasikan dana untuk memperoleh keuntungan yang sebesar-besarnya. Penelitian ini bertujuan untuk menganalisis pengaruh kinerja perusahaan (ROE), kemampuan perusahaan menghasilkan laba (ROA), Earning Per Share (EPS), Net Profit Margin (NPM), Tingkat Inflasi, dan Ukuran Perusahaan (Size), terhadap return saham perusahaan manufaktur yang terdaftar di Bursa Efek Indonesia dalam pengamatan tahun 2012-2016 dengan menggunakan regresi pada aplikasi SPSS 20.

Data yang digunakan merupakan data sekunder yang diperoleh dari Jakarta Stock Exchange (JSX) Yearly Statistic, Indonesia Capital Market Directory (ICMD) dan Yahoo Finance dengan periode waktu 2012 hingga 2016. Jumlah populasi penelitian ini adalah 35 Perusahaan dan jumlah sampel sebanyak 30 perusahaan dengan melewati tahap purposive sampling.

Hasil dari penelitian ini adalah Return On Equity (ROE), Return on Assets (ROA), EPS, NPM, dan Size berpengaruh positif terhadap return saham dan inflasi berpengaruh negatif terhadap return saham tidak berpengaruh signifikan terhadap return saham.
\end{abstract}

Kata Kunci : Return On Equity (ROE), Return on Assets (ROA), EPS, NPM, Inflasi dan Size

\section{PENDAHULUAN}

Dalam era global pertumbuhan perusahaan manufaktur dalam kegiatannya juga ditopang modal dari investor, oleh sebab itu perusahaan manufaktur harus dapat menjaga kesehatan keuangan atau likuiditasnya. Keadaan tersebut menuntut kebutuhan dana yang cukup bagi perusahaan manufaktur untuk bertahan dan bersaing. Salah satu cara yang diambil perusahaan untuk memenuhi kebutuhan dana guna mengembangkan agar tetap bersaing adalah penjualan saham perusahaan kepada masyarakat melalui pasar modal.

Keberadaan pasar modal di Indonesia merupakan salah satu faktor penting bagi perekonomian suatu negara karena pasar modal menjalankan dua fungsi, yaitu pertama sebagai sarana bagi pendanaan usaha atau sebagai sarana bagi perusahaan untuk mendapatkan dana dari masyarakat pemodal atau investor. Dengan adanya fungsi ini perusahaan dapat meningkatkan operasional perusahaan yang juga meningkatkan keuntungan yang diperoleh sehingga akhirnya sistem perekonomian suatu bangsa dapat lebih maju (Jogiyanto, 2013). 
Adapun perbedaan penelitian ini dengan penelitian sebelumnya adalah Penelitian ini secara khusus meniliti sektor barang konsumsi di dalam sektor manufaktur. Disamping itu penelitian sebelumnya hanya meneliti faktor internal perusahaan terhadap return saham seperti halnya pada penelitian Sugiarto (2011) dan Solechan (2010). Pada penelitian ini akan menambah variabel fundamental eksternal perusahaan yaitu variabel ekonomi makro yang dijabarkan menjadi inflasi. Berdasarkan latar belakang yang telah diuraikan oleh peneliti, maka yang menjadi pertanyaan dalam penelitian ini adalah sebagai berikut: (1) Bagaimanakah pengaruh kinerja perusahaan (ROE) terhadap return saham pada perusahaan manufaktur sektor barang konsumsi? (2) Bagaimanakah kemampuan perusahaan (ROA) terhadap return saham pada perusahaan manufaktur sektor barang konsumsi? (3) Bagaimanakah Earning Per Share (EPS) terhadap return saham pada perusahaan manufaktur sektor barang konsumsi? (4) Bagaimanakah pengaruh Net Profit Margin (NPM) terhadap return saham pada perusahaan manufaktur sektor barang konsumsi? (5) Bagaimanakah pengaruh ukuran perusahaan (ROE) terhadap return saham pada perusahaan manufaktur sektor barang konsumsi? (6) Bagaimanakah pengaruh ekonomi makro (Inflasi) terhadap return saham pada perusahaan manufaktur sektor barang konsumsi?

\section{KAJIAN PUSTAKA}

\section{Teori Investasi}

Menurut Jogiyanto (2013) konsumsi dan investasi merupakan dua kegiatan yang berkaitan. Penundaan konsumsi sekarang dapat diartikan sebagai investasi untuk konsumsi di masa mendatang.

\section{Teori Efisiensi Pasar (Market Efficiency Theory)}

Teori efisiensi pasar adalah teori yang membahas tentang harga atau nilai sekuritas yang mencerminkan secara penuh semua informasi yang tersedia pada informasi tersebut (Hanafi, 2004).

\section{Teori Keagenan}

Teori keagenan menggambarkan perusahaan sebagai suatu titik temu antara pemilik perusahaan (principal) dengan manajemen (agent). Jensen dan Meckling (1976) menyatakan bahwa hubungan keagenan merupakan sebuah kontrak yang terjadi antara manajer (agent) dengan pemilik perusahaan (principal) yang mempunyai kepentingan yang berbeda. 


\section{Return Saham}

Mayo (2007) mengemukakan pengertian return adalah apa yang diterima dalam suatu investasi; jumlah pendapatan dan keuntungan modal yang dihasilkan oleh investasi. Jogiyanto (2013) mengemukakan definisi return merupakan hasil yang diperoleh dari investasi.

\section{Kinerja Perusahaan (ROE)}

Kinerja keuangan suatu perusahaan dapat diartikan sebagai prospek atau masa depan, pertumbuhan dan potensi perkembangan yang baik bagi perusahaan (Orniati, 2009). Alat ukur kinerja perusahaan dipakai oleh pihak manajemen sebagai acuan untuk mengambil keputusan dan mengevaluasi kinerja manajemen dan unit-unit terkait di lingkungan organisasi perusahaan (Husnan dan Pudjiastuti, 2004).

\section{Kemampuan Perusahaan (ROA)}

Menurut Sartono (2001:131), “Return on assets menunjukkan kemampuan perusahaan menghasilkan laba dari aktiva yang dipergunakan". Jadi return on assets (ROA) merupakan suatu rasio yang menggambarkan laba yang bisa diperoleh perusahaan dari aktiva yang dimilikinya. Semakin tinggi nilai dari return on assets menunjukkan bahwa modal yang diinvestasikan oleh perusahaan dalam keseluruhan aktiva yang dimilikinya menghasilkan keuntungan neto yang semakin tinggi.

\section{Earning Per Share (EPS)}

Menurut Syamsuddin (2004:66), dikatakan bahwa "Earning per share menggambarkan jumlah rupiah yang diperoleh untuk setiap lembar saham biasa”.

\section{Net Profit Margin (NPM)}

Menurut Hanafi dan Halim (2005:86), " Net profit margin menghitung sejauh mana kemampuan perusahaan menghasilkan laba bersih pada tingkat penjualan tertentu".

\section{Ukuran Perusahaan (Size)}

Menurut Purnomosidi et al (2014) ukuran perusahaan dapat ditunjukkan dengan total asset, total sales, average sales rate dan average total assets. Perusahaan dengan skala besar akan lebih mudah memperoleh pinjaman bila dibandingkan dengan perusahaan kecil. Perusahaan yang besar memiliki pertumbuhan yang lebih besar dibandingkan dengan perusahaan kecil sehingga tingkat return saham perusahaan besar lebih besar dari return saham perusahaan kecil.

\section{Tingkat Inflasi}

Romer (1996) yang menjelaskan bahwa inflasi sendiri didefinisikan sebagai gejala kenaikan harga secara permanen, merupakan hasil interaksi dari permintaan dan penawaran yang bekerja melalui 
mekanisme pasar. Menurut Prihantini (2009) menjelaskan bahwa penyebab terjadinya inflasi yang mempengaruhi perekonomian yaitu melalui pendapatan dan kekayaan dan melalui perubahan tingkat dan efisiensi produksi.

Berdasarkan kerangka pemikiran maka hipotesis yang diajukan sebagai berikut :

Hipotesa Pertama : Kinerja Perusahaan (ROE) berpengaruh signifikan terhadap return saham

Hipotesa Kedua : Kualitas Perusahaan (ROA) berpengaruh signifikan terhadap return saham

Hipotesa Ketiga : Earning Per Share (EPS) berpengaruh signifikan terhadap return saham

Hipotesa Keempat : Net Profit Margin (NPM) berpengaruh signifikan terhadap return saham

Hipotesa Kelima : Inflasi tidak berpengaruh signifikan terhadap return saham

Hipotesa Keenam : Size berpengaruh signifikan terhadap return saham

\section{$\underline{\text { Rerangka Konseptual }}$}

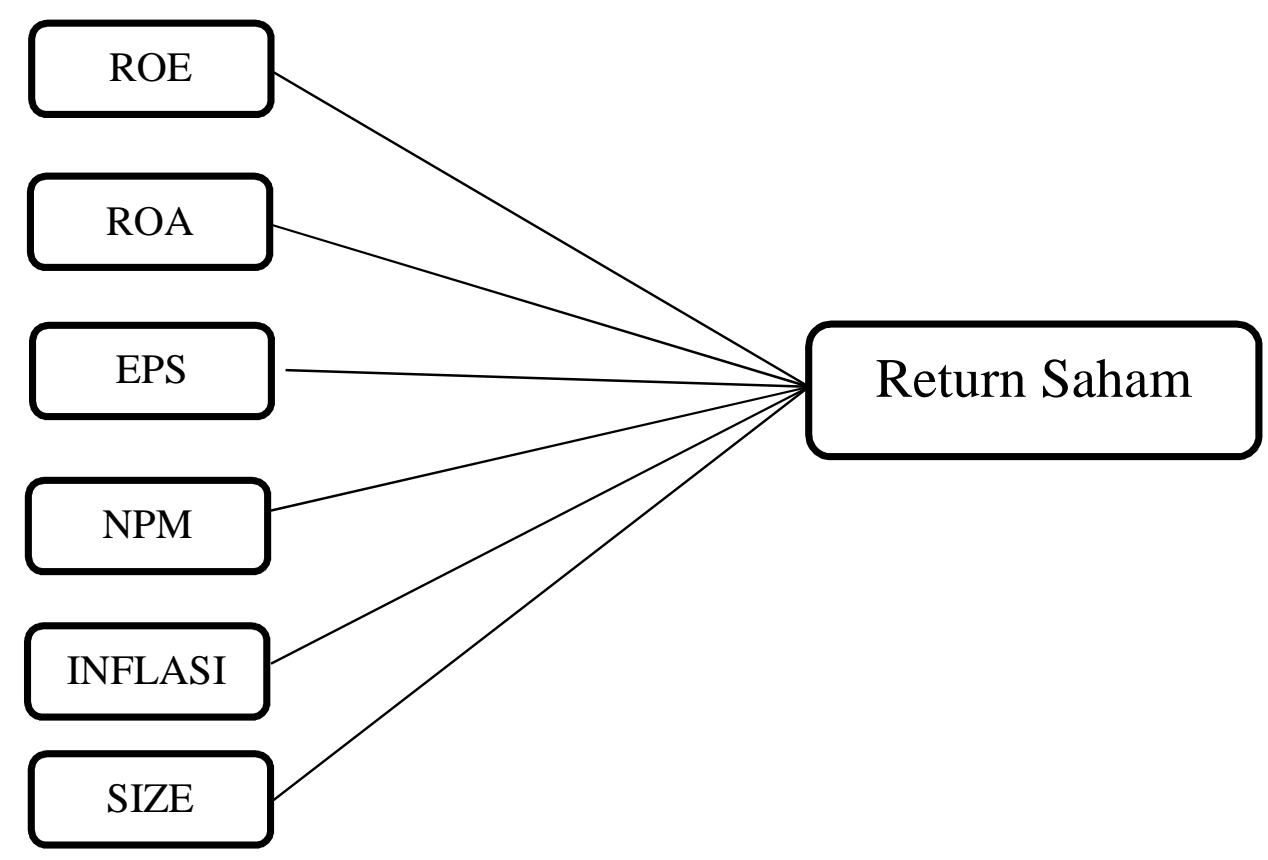

\section{METODE PENELITIAN}

\section{Variabel Penelitian}

Data yang digunakan dalam penelitian ini adalah data sekunder yang bersifat kuantitatif berupa pooling data dengan metode pengamatan saham-saham pada sektor manufaktur sektor barang konsumsi dari tahun 2012 sampai dengan 2016. Penelitian menggunakan metode analisis regresi berganda yang sebelumnya akan diuji asumsi sebagai persyaratan uji analisis regresi. 


\section{PEMBAHASAN}

\section{Uji Normalitas}

One-Sample Kolmogorov-Smirnov Test

\begin{tabular}{|ll|r|}
\hline & & $\begin{array}{r}\text { Unstandardiz } \\
\text { ed Residual }\end{array}$ \\
\hline $\mathrm{N}$ & 150 \\
Normal Parameters a,b & Mean & .0000000 \\
& Std. Deviation & .49391031 \\
Most Extreme & Absolute & .095 \\
Differences & Positive & .095 \\
& Negative & -.071 \\
Kolmogorov-Smirnov Z & & 1.161 \\
Asymp. Sig. (2-tailed) & & .135 \\
\hline
\end{tabular}

a. Test distribution is Normal.

b. Calculated from data.

besarnya nilai Kolmogorov-Smirnov adalah 1,161 dan signifikan pada 0,135 dan nilainya lebih besar dari 0,05. Hal ini menunjukkan bahwa data residual terdistribusi secara normal.

\section{Uji Multikolonieritas}

\begin{tabular}{|ll|c|c|}
\hline \multirow{2}{*}{ Model } & & \multicolumn{2}{|c|}{ Collinearity Statistics } \\
\cline { 2 - 4 } & & Tolerance & VIF \\
\hline & ROE & .892 & 1.120 \\
& ROA & .870 & 1.149 \\
& EPS & .947 & 1.056 \\
& NPM & .580 & 1.725 \\
& INFLA S I & .416 & 2.405 \\
& SIZE & .132 & 7.552 \\
\hline
\end{tabular}

Berdasarkan tabel diatas, diketahui bahwa masing-masing variabel independen yang digunakan dalam penelitian memiliki nilai VIF < 10 (atau Tolerance $>0,10$ ), hal ini menunjukkan bahwa pada model regresi terhindar dari masalah multikolinearitas 


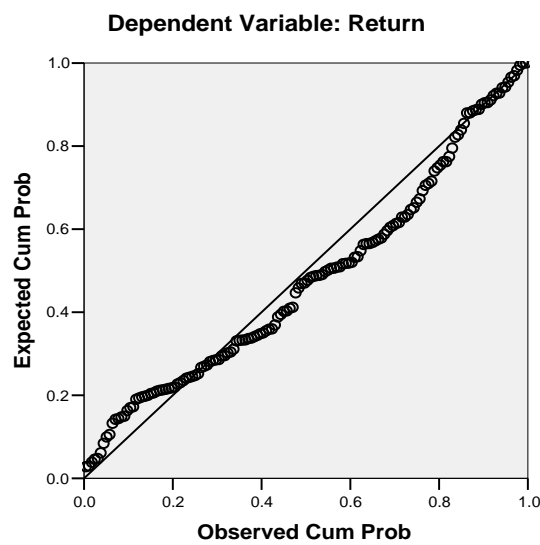

Berdasarkan hasil pengujian normalitas diatas dapat diketahui bahwa terlihat titik-titik menyebar disekitar garis diagonal, serta penyebarannya mengikuti arah garis diagonal, maka dapat disimpulkan bahwa model regresi ini layak dipakai karena memenuhi asumsi normalitas.

\section{Uji Heteroskedastisitas dengan scatter plot}

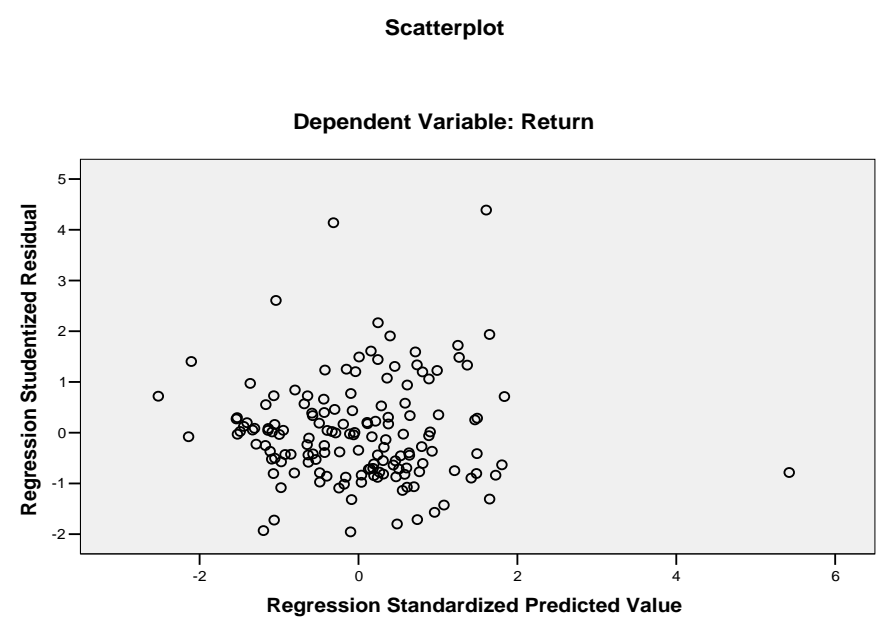

Berdasarkan hasil pengujian heteroskedastisitas diatas, dengan scatter plot, terlihat bahwa titik - titik yang ada tidak membentuk pola tertentu yang teratur (bergelombang, melebar kemudian menyempit) dan titik - titik menyebar disekitar angka 0 pada sumbu y, maka mengidikasikan tidak terjadi masalah heteroskedastisitas. 
Model Summary

\begin{tabular}{|l|r|r|r|r|}
\hline Model & R & R Square & $\begin{array}{c}\text { Adjusted } \\
\text { R Square }\end{array}$ & $\begin{array}{c}\text { Std. Error of } \\
\text { the Estimate }\end{array}$ \\
\hline 1 & $.494^{\mathrm{a}}$ & .244 & .207 & .505938 \\
\hline
\end{tabular}

Dari tabel di atas, dapat dilihat bahwa koefisien (r) yaitu sebesar 0.494. nilai tersebut menunjukkan bahwa korelasi atau hubungan antara ROE, ROA, EPS,NPM, INFLASI, SIZE, dengan Return dinyatakan memiliki hubungan yang kuat dikarenakan memiliki nilai korelasi $>0.50$.

Sedangkan nilai Adjusted R Square (koefisien determinasi) dihasilkan angka sebesar 0.207 yang berarti bahwa variasi variabel Return dapat dijelaskan oleh variabel ROE, ROA, EPS,NPM, INFLASI, SIZE adalah sebesar 0.207 atau sebesar $20.7 \%$ sedangkan sisanya sebesar $79.3 \%$ dijelaskan oleh faktor-faktor lain yang tidak terdapat dalam penelitian ini.

\section{Hasil Uji t}

\begin{tabular}{|c|c|c|c|c|c|c|}
\hline \multirow[b]{2}{*}{ Mod } & & \multicolumn{2}{|c|}{$\begin{array}{l}\text { Unstandardized } \\
\text { Coef f icients }\end{array}$} & \multirow{2}{*}{$\begin{array}{c}\begin{array}{c}\text { Standardized } \\
\text { Coeff icients }\end{array} \\
\text { Beta }\end{array}$} & \multirow[b]{2}{*}{$t$} & \multirow[b]{2}{*}{ Sig. } \\
\hline & & B & Std. Error & & & \\
\hline \multirow[t]{7}{*}{1} & (Constant) & 1.53230 & .782 & & 1.958 & .052 \\
\hline & ROE & .25989 & .121 & .166 & 2.153 & .033 \\
\hline & ROA & .06298 & .026 & .187 & 2.391 & .018 \\
\hline & EPS & .08096 & .032 & .190 & 2.528 & .013 \\
\hline & NPM & -7.66099 & 2.930 & -.251 & -2.614 & .010 \\
\hline & INFLASI & -.00633 & .003 & -.086 & -2.429 & .669 \\
\hline & SIZE & -.06109 & .142 & -.241 & -2.133 & .035 \\
\hline
\end{tabular}

\section{a. Dependent Variable: Return}

Berdasarkan pada tabel di atas dapat dikatakan bahwa variable ROE dengan tingkat signifikansi sebesar 0.033 dimana nilai $0.033<0.05$ dan karena itu dapat disimpulkan bahwa Ha diterima atau Ho ditolak yang berarti variable ROE berpengaruh secara positif signifikan terhadap Return dengan koefisien beta sebesar 0.166 yang berarti setiap ada peningkatan variabel ROE sebesar satu satuan maka akan meningkatkan Return sebesar 0.166

Berdasarkan pada tabel di atas dapat dikatakan bahwa variable ROA dengan tingkat signifikansi sebesar 0.018 dimana nilai $0.018<0.05$ dan karena itu dapat disimpulkan bahwa Ha diterima atau Ho ditolak yang berarti variable ROA berpengaruh secara positif signifikan terhadap Return dengan koefisien beta sebesar 0.187 yang berarti setiap ada peningkatan variabel ROA sebesar satu satuan maka akan meningkatkan Return sebesar 0.187

Berdasarkan pada tabel di atas dapat dikatakan bahwa variable EPS dengan tingkat signifikansi sebesar 0.013 dimana nilai $0.013<0.05$ dan karena itu dapat disimpulkan bahwa Ha diterima atau Ho ditolak yang berarti variable EPS berpengaruh secara positif signifikan terhadap Return dengan koefisien beta 
sebesar 0.187 yang berarti setiap ada peningkatan variabel EPS sebesar satu satuan maka akan meningkatkan Return sebesar 0.187

Berdasarkan pada tabel di atas dapat dikatakan bahwa variable NPM dengan tingkat signifikansi sebesar 0.010 dimana nilai $0.010<0.05$ dan karena itu dapat disimpulkan bahwa Ha diterima atau Ho ditolak yang berarti variable NPM berpengaruh secara negatif signifikan terhadap Return dengan koefisien beta sebesar 0.251 yang berarti setiap ada peningkatan variabel NPM sebesar satu satuan maka akan menurunkan Return sebesar 0.251

Berdasarkan pada tabel di atas dapat dikatakan bahwa variable Inflasi dengan tingkat signifikansi sebesar 0.669 dimana nilai $0.669>0.05$ dan karena itu dapat disimpulkan bahwa Ha ditolak atau Ho diterima yang berarti variable Inflasi tidak berpengaruh secara negatif signifikan terhadap Return dengan koefisien beta sebesar -0.086 yang berarti setiap ada peningkatan variabel Inflasi sebesar satu satuan maka akan menurunkan Return sebesar 0.086

Berdasarkan pada tabel di atas dapat dikatakan bahwa variable Size dengan tingkat signifikansi sebesar 0.035 dimana nilai $0.035<0.05$ dan karena itu dapat disimpulkan bahwa Ha diterima atau Ho ditolak yang berarti variable NPM berpengaruh secara negatif signifikan terhadap Return dengan koefisien beta sebesar 0.241 yang berarti setiap ada peningkatan variabel Size sebesar satu satuan maka akan menurunkan Return sebesar 0.241

\section{Hasil Uji F}

\begin{tabular}{|l|r|r|r|r|c|}
\hline Model & $\begin{array}{c}\text { Sum of } \\
\text { Squares }\end{array}$ & df & Mean Square & F & Sig. \\
\hline 1 & 11.726 & 7 & 1.675 & 6.544 &.$^{000}$ \\
Regression & 36.348 & 142 & .256 & & \\
\multicolumn{1}{|c|}{ Residual } & 48.074 & 149 & & & \\
\hline
\end{tabular}

Berdasarkan hasil analisis regresi yang disajikan dalam Tabel di atas tampak bahwa dengan uji ANOVA atau $\mathrm{F}$ test didapat $\mathrm{F}$ hitung sebesar 6.544 (F tabel sebesar : 2.00) dengan tingkat signifikan 0,000. Oleh karena $\mathrm{F}$ hitung lebih besar dari $\mathrm{F}$ tabel dan probabilitas jauh lebih kecil dari 0,05 yang berarti $\mathrm{Ha}$ diterima yang dapat dikatakan bahwa ROE, ROA, EPS,NPM, INFLASI, SIZE, secara bersama-sama memiliki pengaruh terhadap Return

\section{Kesimpulan dan Saran}

Berdasarkan pengujian analisis yang dilakukan melalui uji korelasi, uji regresi secara parsial dan uji regresi secara berganda diketahui bahwa setiap variabel yang ada baik itu variabel Kompensasi, variabel Pelatihan dan variabel Motivasi, keseluruhan nilai t hitung dan $\mathrm{f}$ hitungannya lebih besar daripada nilai $\mathrm{t}$ table dan $\mathrm{f}$ table, sehingga keseluruhan hipotesa yang diajukan dalam penelitian ini dapat diterima.

\section{Saran}


Berdasarkan keterbatasan yang diuraikan, maka saran dari penelitian ini adalah ;

1. Bagi Perusahaan

Perusahaan manufaktur sektor barang konsumsi yang terdaftar di Bursa Efek Indonesia diharapkan memperhatikan kondisi harga saham dan faktor ekonomi makro yang mempengaruhi harga saham. Pada perubahan saham yang terlalu tinggi akan pula meningkatkan beta saham dari return sahamnya dan pada kondisi ini kemudian akan membuat investor akan menghindari resiko (risk averter).

2. Bagi Investor dan Calon Investor

Investor dan calon investor diharapkan untuk memiliki pengetahuan mengenai analisa investasi yang tepat sebelum mengambil keputusan investasi baik yang bersifat fundamental perusahaan namun faktor ekonomi negara karena walau bagaimanapun, pemerintah secara tidak langsung memiliki andil dalam perekonomian keseluruhan masyarakat dan berdampak pada aktivitas operasional perusahaan.

3. Bagi Pemerintah

Pemerintah diharapkan dapat lebih mengembangkan aktivitas pasar modal melalui kebijakan regulasi yang dapat meningkatkan minat masyarakat terhadap pasar modal dan mempublikasikan informasi mengenai pasar modal mengingat pasar modal merupakan cerminan majunya perekonomian suatu negara mengingat masih minimnya minat masyarakat terhadap pasar modal.

\section{Daftar Pustaka}


Abu-Ali, Mohammed. 2003. The Relationship Between Inflation and Stock Return Revisited: A New Empirical and Narrative Investigation. George Manson University.

Choudry, T.2000. Day of The Week Effect in Emerging Asian Stock Markets, Financial Economic: Vol.10 No.3

Cahyono. Jaka E. 2000. Strategi dan Tehnik Meraih Untung di Bursa Saham. Jil 1. Jakarta: PT.Elex Media Komputindo.

Eko Supriyanto dan Falikhatun. 2008. Pengaruh Tangibility, Pertumbuhan Penjualan dan Ukuran Perusahaan Terhadap Struktur Keuangan. Jurnal Bisnis dan Akuntansi

Darmawi.Herman.2006. Pasar Finansial dan Lembaga-Lembaga Finansial. PT.Bumi Aksara

Endri. 2009. Keterkaitan Dinamis Faktor Fundamental Makro Ekonomi dan Imbal Hasil saham. Jurnal Bisnis dan Akuntansi Vol.11 No.2 hal 79-95.

Daniati, Ninna \& Suhairi, 2006.Pengaruh Kandungan Informasi Komponen Laporan Arus Kas, Laba Kotor, dan Size Perusahaan Terhadap Expected Return Saham. Jurnal Simposium Nasional Akuntansi 9. Padang.hal 1-23

Dornbusch, R. dan S.Fischer. 1992. Makroekonomi. Terjemahan. Erlangga, Jakarta.

Fidhayatin, Septy \& Dewi. Nurul Hasanah Uswati. 2012. Analisis Nilai Perusahaan, Kinerja Perusahaan dan Kesempatan Bertumbuh Perusahaan Terhadap Return Saham Pada Perusahan Manufaktur yang Listing di BEI. STIE Perbanas. Jakarta.Hal 203-214.

Ghozali, Imam. 2013. Aplikasi Analisis Multivariate dengan Program. Edisi Ketujuh. Semarang: Badan Penerbit Universitas Diponegoro.

Hartati, Enny Sri. 2004. Analisis Dampak Pergerakan Nilai Tukar Terhadap Inflasi di Indonesia: Pendekatan Exchange Rate Pass-Through. Tesis. Sekolah Pascasarjana Institut Pertanian Bogor

Hartono. 2008. Pengaruh Multifaktor Makro Ekonomi Terhadap Return Pasar. Jurnal Manajemen Bisnis Syariah, Vol. II No.01, 38-39, 46.

Hernendiastoro,Andre.2005. Pengaruh Kinerja Perusahaan dan Kondisi Ekonomi Terhadap Return Saham Dengan Metode Intervalling (Studi Kasus Pada Saham-Saham LQ 45). Universitas Diponegoro. Semarang.Tesis

Herman Budi Santoso. 2003. Pengaruh Perbedaan Laju Inflasi dan Suku Bunga Pada Nilai Tukar Rupiah Terhadap Dollar Amerika, dalam Kurun Waktu Januari 2000 - Desember 2002. Majalah Ekonomi XIII. No.3 Desember

Husnan, Suad.1996. Dasar-Dasar Teori Portofolio, YKPN Cetakan kedua.

Hutami Rescyana Putri.2012. Pengaruh Dividend Per Share, Return On Equity dan Net Profit Margin Terhadap Harga Saham Perusahaan Industri Manufaktur Yang Tercatat di Bursa Efek Indonesia Periode 2006-2010. Jurnal Ekonomi dan Bisnis Volume 1 No.1 
Halim, Abdul.2005. Analisis Investasi. Salemba Empat Edisi Kedua.

Iswardono. 1999. Suku Bunga Diturunkan Investasi Akan Meningkat. Jurnal Ekonomi dan Bisnis Indonesia. Vol.14. No.2

Indraloka, Dimas Ngurah. "Analisis Pengaruh Variabel Makroekonomi dan harga Minyak Dunia terhadap IHSG di BEI”. Skripsi FEB Manajemen, Universitas UIN Syahida.Jakarta.2010.

Juliah. 2009. Pengaruh Kapitalisasi Pasar, Tingkat Inflasi, dan Tingkat Suku Bunga SBI Terhadap Return Saham (Studi Pada Perusahaan Bergerak dalam Bidang Finansial di BEI) Jurnal Bisnis dan Akuntansi. Vol.13 No.2 Agustus 2011, Hlm 107-118.

Erni, Ervita, Ratna. 2012. Pengaruh Inflasi dan Tingkat Suku Bunga Terhadap Return Saham PT.Indofood Sukses Makmur Tbk. Jurnal STIE MDP.Jakarta

Jensen, M. C and Meckling, W.H. 1976. Theory of the Firm : Managerial Behavior, Agency Costs and Ownership Structure. Journal of Financial Economics, Oktober, 1976, V. 3, No. 4, pp. 305-360.

Jones, Charles P.2004. Investment Analysis and Management 9th ed New York : John Wiley and Sons

Jogiyanto, Hartono.2013. Teori Portfolio dan Analisis Investasi, Yogyakarta:BPFE

Junaedi, Dedi.2005. Dampak Tingkat Pengungkapan Informasi Perusahaan Terhadap Volume Perdagangan Dan Return Saham: Penelitian Empiris Terhadap Perusahaan-Perusahaan Yang Tercatat di Bursa Efek Jakarta. Jurnal Akuntansi dan Keuangan Indonesia Vol.2 No.2. Jakarta.

Karanovic, Goran, Bogdan, Sinisa and Baresa, Suzana. 2010. Financial Analysis Fundament For Assessment The Value Of The Company, UTMS Journal of Economics, Vol. 1, No.1. pp 73-78

Kementerian Perindustrian Republik Indonesia, "Kuartal I, Industri Manufaktur Tumbuh 6,2\%" www.kemenperin.go.id

Kewal, Suramaya Suci.2012. Pengaruh Inflasi, Suku Bunga, Kurs Dan Pertumbuhan PDB Terhadap Indeks Harga Saham Gabungan. Jurnal Economia Vol.8 No.1 Hal 53-64.

Killian, Lutz dan Cheolbeom Park. 2007. The Impact of Oil Price Shocks on the U.S. Stock Market. International Economic Review Vol.50.No.4. University of Michigan. USA.,and CEPR; Korea University, Korea.

Krisis Keuangan Eropa: Dampak Terhadap Perekonomian Indonesia. Laporan Perekonomian Kementerian Perencanaan Pembangunan/Bapenas Triwulan IV tahun 2011.

Lutfi, Yudhi M. Dan Dyasanti, Adhystia.2006. Analisis Pengaruh Variabel Keterbukaan Ekonomi, Tingkat Suku Bunga Domestik, Tingkat Suku Bunga Asing

Lukman, Purnomosidi. 2014. The Influences of Company Size, Capital Structure, Good Corporate Governance, Inflation, Interest Rate, and Exchange Rate of Financial Perfomance and Value of The Company. Universitas Brawijaya.

Mankiw N Gregory. 2003 “Macroeconomics”. Ninth Edition. Newyork:McGraw-Hill.2003. 
Mayo, Herberth B. An Introduction To Institutions, Management, And Investments.Edisi 10.Hal4-5 dan 152.

Nasser, Etty.2013.Pengaruh Beta Saham Terhadap Expected Return Dengan Model Capital Asset Pricing Pada Perusahaan Publik di Bursa Efek Jakarta. Universitas Trisakti. Jakarta. Hal 163-186.

Nachrowi, D. Nachrowi. 2006. Ekonometrika: Pendekatan Populer dan Praktis untuk Analisis Ekonomi dan Keuangan. LPFE UI, Jakarta.

Nezky, Mita (2013). Pengaruh Krisis Ekonomi Amerika Serikat Terhadap Bursa Saham Dan Perdagangan Indonesia. Buletin Ekonomi Moneter dan Perbankan Januari. Jakarta.Hal 89-103.

Nuryaman. 2008. Pengaruh Konsentrasi Kepemilikan Umum Perusahaan dan Mekanisme Corporate Governance Terhadap Manajemen Laba. Simposium Nasional Akuntansi XI. Pontianak

Novis. 2003. Perkembangan Ekonomi Makro Indonesia dan Pengaruhnya Terhadap Dunia Usaha Khususnya Bisnis Asuransi. Jurnal Bisnis dan Akuntansi. Vol.13 No.2 Agustus 2011, Hlm 107118.

Orniati Yuli.2009. Laporan Keuangan SebagaiAlat Untuk Menilai Kinerja Keuangan. Jurnal Ekonomi Bisnis Tahun 14 No.3.hal 206-213.

Purnomosidi, Lukman. 2014. The Influence of Company Size, Capital Structure, Good Corporate Governance, Inflation, Interest Rate, and Exchange Rate Of Financial Performance and Value Of The Company Interdisciplinary Journal Of Contemporary Research in Business.

Prihantini Ratna. 2009. Analisis Pengaruh Inflasi, Nilai Tukar, ROA, DER dan CR Terhadap Return Saham. Universitas Diponegoro, Semarang.

Rusliati, Ellen dan Fathoni, Syarah Nurul.2011.Inflasi, Suku Bunga Deposito, dan Return Pasar Terhadap Return Saham Pada Industri Barang Konsumsi Yang Terdaftar di BEI 2006-2009. Jurnal Bisnis dan Akuntansi Vol.13 No.2

Reilly, Frank K. and Keith C. Brown. 2003. Investment Analysis \& Portfolio Management. Seventh Edition. South Western a division of Thomson Learning Ohio, USA.

Reilly and Brown (2009). Analysis of Investments and Management of Portfolios. Edisi 10.

Roomer, David. 1996. Advanced Macroeconomics.McGraw-Hill.

Sangeroki, Seyla. 2013. Ukuran Perusahaan, Margin Laba Kotor Terhadap Pemilihan Metode Penilaian Persediaan di Perusahaan Manufaktur. Jurnal EMBA Vol.1 No.3 Hal 1185-1192.

Septian, Masodah, Riskayanto, dan Septi. 2012. Analisis Pengaruh Tingkat Inflasi, Harga Minyak Dunia, Harga Emas Dunia, Dan Kurs Rupiah Terhadap Pergerakan Jakarta Islamic Index di Bursa Efek Indonesia. Jurnal Forum Bisnis dan Keuangan I.

Setianungrum, Rosakrina.2009. Pengaruh Faktor-Faktor Fundamental dan Risiko Sistematik Terhadap Harga Saham (Studi Kasus Pada Perusahaan Manufaktur Yang Listed di BEI). Universitas Sebelas Maret Surakarta. Tesis 
Sihono, Teguh. 2008. Krisis Finansial Amerika Serikat dan Perekonomian Indonesia. Jurnal Ekonomi \& Pendidikan Vol.5 No.2. Hal 171-192.

Solechan, Achmad.2010. Pengaruh Earning Manajemen Laba, IOS, Beta, Size dan Rasio Hutang Terhadap Return Saham Pada Perusahaan yang Go Public di BEI. STMIK HIMSYA.Semarang.

Suad Husnan dan Enny Pudjiastuti. 2004. Dasar-dasar Manajemen Keuangan.UPP AMP YKPN. Yogyakarta

Sudiyanto, Bambang.2010. Peran Kinerja Perusahaan Dalam Menentukan Pengaruh Faktor Fundamental Makro Ekonomi, Risiko Sistematis, dan Kebijakan Perusahaan Terhadap Nilai Perusahaan. Semarang. Disertasi.

Sugiarto, Agung. 2011. Analisa Pengaruh Beta, Size Perusahaan, DER, dan PBV Ratio Terhadap Return Saham. UNIKA Soegijapranata. Semarang. Hal 8-14.

Suherman, Anwar Siburian. 2013.Pengaruh Earning Per Share, Debt to Equity Ratio, Return on Equity, dan Price to Book Value terhadap Return Saham. Jurnal Riset Manajemen Sains Indonesia (JRMSI). Vol.4.No.1

Supriyanto, Eko dan Falikhatun.2008. Pengaruh Tangibility, Pertumbuhan dan Ukuran Perusahaan Terhadap Struktur Keuangan. Jurnal Bisnis dan Akuntansi Vol.10 No.1. hal 13-22.

Sustriani, Anis. 2014. Pengaruh Profitabilitas, Leverage, dan Likuiditas Terhadap Return Saham Dengan Nilai Tukar Sebagai Variabel Moderasi Pada Saham LQ-45. Journal of Business and Banking Vol.4 No.1 Hal 67-80.

Suyanto. 2007. Analisis Pengaruh Nilai Tukar Uang, Suku Bunga dan Inflasi Terhadap Return Saham Sektor Properti yang tercatat di Bursa Efek Jakarta. Tesis. Semarang: Program Pasca Sarjana Universitas Diponegoro Semarang.

Triayuningsih, Retno. 2003. "Analisis Pengaruh Kinerja Keuangan Perusahaan dan Faktor Ekonomi Makro Terhadap Return Saham Perusahaan Industri Manufaktur di BEJ Periode 19992001’.Tesis. Semarang: Program Pasca Sarjana Universitas Diponegoro Semarang.

Ujiyanto dan Bambang. 2007. Mekanisme Corporate Governance, Manajemen Laba dan Kinerja Keuangan. Simposium Nasional Akuntansi X

Usman, Bahtiar. 2007. Pengaruh Suku Bunga Deposito, PDB, dan Volume Perdagangan Saham Terhadap IHSG di Indonesia (Penggunaan Model Arch-Garch. Kointegrasi dan ECM). Media Riset Bisnis dan Manajemen.Vol.7.No.1

Utami dan Rahayu. 2003. Peranan Profitabilitas, Suku Bunga, Inflasi dan Nilai Tukar dalam Mempengaruhi Pasar Modal Indonesia Selama Krisis Ekonomi. Jurnal Manajemen \& Kewirausahaan. Vol.5.No.2

Utomo, Welly. 2007. Analisis Pengaruh Beta dan Varian Return Saham Terhadap Return Saham. Universitas Diponegoro. Semarang. Tesis 
Wahyudi, Sugeng. 2004. Perkembangan dan Prospek Pasar Modal di Indonesia Tahun 2005 (Event Study : Pendekatan Manajemen Strategik). Jurnal Bisnis Strategi.Vol.13 No.8,7.

Yasmiandi, Fauzan.2011. Analisis Pengaruh Inflasi, Nilai Tukar, Suku Bunga, Harga Minyak dan Harga Emas Terhadap Return Saham. Skripsi. Universitas Islam Negeri

Yulia, Oky dan Sro Desinta. 2004. Analisis Harga Saham, Ukuran Perusahaan, dan Risiko Terhadap Return yang Diharapkan Investor Pada Perusahaan-Perusahaan Saham Aktif. Jurnal Balance 1 Universitas Katolik Indonesia Atma Jaya. Jakarta. Hal 56-72 